\title{
The Branding Impact on Charity Product Marketing Communication
}

\author{
Hilarius Bambang Winarko* \\ Program Studi Manajemen, Sampoerna University \\ Jl. Raya Pasar Minggu Kav. 16, Jakarta, Indonesia \\ bambang.winarko@sampoernauniversity.ac.id
}

Lawrence Sa Benning

PT. Glints Indonesia

GoWork Fatmawati, Jl. R.S. Fatmawati Raya, Jakarta, Indonesia

lawrencesabenning@gmail.com

\section{Sri Tunggul Pannindriya}

Program Studi Ilmu Komunikasi, LSPR Communication \& Business Institute

Jl. Ir. H. Juanda No. 220, Bekasi, Indonesia

tunggul.p@lspr.edu

Received: 09-02-2021

Accepted: 16-06-2021

Published: 30-06-2021

\begin{abstract}
ABSTRAK
Penelitian ini bertujuan untuk mengisi gap penelitian tentang sikap pembelian milenial terhadap produk amal pada brand sepatu Youth of Indonesia (YoI) yang dipromosikan melalui media sosial. Tujuan penelitian ini adalah untuk mengetahui bagaimana pengaruh unsur-unsur branding terhadap niat beli sepatu YoI dengan menggunakan metode penelitian kuantitatif. Penelitian ini melibatkan 222 responden milenial valid yang tinggal di wilayah metropolitan Jakarta. Lima elemen merek digunakan sebagai variabel independen; mereka adalah kesadaran merek, persepsi kualitas, asosiasi merek, loyalitas merek, dan kredibilitas merek. Berdasarkan hasil regresi linier berganda, dilaporkan bahwa kesadaran merek, persepsi kualitas, dan asosiasi merek tidak berpengaruh signifikan terhadap niat beli para milenial. Namun loyalitas merek dan kredibilitas merek berpengaruh secara signifikan positif. Antara variabel-variabel tersebut, kredibilitas merek merupakan faktor terpenting yang mempengaruhi minat beli para milenial serta strategi komunikasi pemasaran produk amal ini.
\end{abstract}

Kata Kunci:

Amal; Branding; Buy-One Give-One; Komunikasi Pemasaran; Pemasaran Digital; Milenial

\begin{abstract}
This study aims to fill the research gap on millennial's purchase attitude toward charity product in Youth of Indonesia (YoI) brand shoes which is promoted through social media. The research objective is to understand how branding elements affect the purchase intention of YoI shoes by using quantitative research method. There were 222 millennial valid respondents who are living in Jakarta metropolitan area participated in this research. The five brand elements are used as independent variables; they are brand awareness, perceived quality, brand association, brand loyalty, and brand credibility. Based-on the multiple linear regression output, it reports that brand awareness, perceived quality, and brand association do not have significant impact toward the millennial's purchase intention. However, the brand loyalty and brand credibility give positive significant impact. Among others, the brand credibility is the most important factor that influence the millennial's purchase intention as well as marketing communication strategy of this charity product.
\end{abstract}

Keywords:

Branding; Buy-One Give-One; Charity; Digital Marketing; Marketing Communication; Millennial 


\section{INTRODUCTION}

There were several studies mentioned about the behavior of the millennial toward the donation. The millennial is said to have a greedy, narcissistic, and lazy behavior (Koczanski \& Rosen, 2019). In addition, the millennial generation is labelled as a self-absorbed and selfish compared to another generations. The survey also mentions that $71 \%$ millennials in the US are considered as selfish generation (Gillespie, 2014). In contrary, another study reveals that the millennial is considered as a generous generation (Schulte, 2015). These findings show contradicting perspectives toward the charity attitude and behavior of the millennial.

A conducted survey states that millennial in Indonesia is actively allocating their money for a donation. It can be seen that $60.88 \%$ had participated in making donations through social media sites or accounts, meanwhile 39.12\% said they had never donated online (Purnamasari, 2018). It is because the young people in Indonesia have more access to digital technology that triggered them to be more aware of social issues. According to a report, the millennial in Indonesia tend to allocate as much as $5,3 \%$ from their income to do a charity action (IDN Research Institute, 2019). This charity action can be done through online donation platform to support people who are needy.

The data from Indonesia Millennial Report 2019 states that the Indonesian millennial is having strong intention to help others and willing to create a positive movement. Therefore, from 2019 until the present time, online fundraising is becoming common for millennial as a good platform to do positive movement. It indicates that the target market for community or charity-based brand products exists and it may trigger the millennial to buy the product and support Buy-One Give-One (BOGO) program. Reflecting from this trend, this phenomenon may influence the firms to improve its digital marketing communication approach by using charity strategy to gain broader market shares and boost sales revenue.

This study emphasizes and focuses on the millennial because they tend to have a higher consciousness to purchase BOGO charity products. Also, they want to be recognized as a socialconscious generation who have potential ability to make a positive change in the society. Moreover, this research also aims to understand how the brand elements, such as: brand awareness, perceived quality, brand association, brand loyalty, and brand credibility influence the millennial in purchasing Youth of Indonesia (YoI) shoes product, especially those who are living in Jakarta metropolitan area (Jakarta, Bogor, Depok, Tangerang, Bekasi, and its surrounding area).

In a nutshell, this study aims to give important contribution to brand owners on how branding elements as mentioned above can be used effectively to promote their charity product as well as boost profitable sales. This is important because the success of societal marketing communication campaign involves on how to the target audience of typical charity product appreciate the product they purchase and increase their loyalty, while it also may promote welfare for greater society.

The Youth of Indonesia (YoI) shoes is a relatively new shoes brand established under the brand of Men's and Women's Republic, which is targeting for youth communities. It uses eco-friendly and 
sustainable raw materials. The brands use faux leather and canvas, rather than animal leather. The company is also empowering local human resources around Indonesia to take part in their shoes production.

The Youth of Indonesia (YoI) shoes is a product development of Men's and Women's Republic that is created to support social mission, such as improving education in rural areas in Indonesia. This brand is promoted through online social media along with the \#Indonesiamelangkah or \#daretostep hashtags. This product aims to create social value of the brand for customers. The value that this brand tries to emphasize is to give an impact on education for poor society who lives in Flores island, East Nusa Tenggara. The selling mechanism of this product is done by implementing Buy-One Give-One (BOGO) program and donating $100 \%$ percent of its profit for charity purpose. The aim of making this kind of brand product is to sell them to the right target market of youth communities who are keen to purchase the shoes and at the same time giving back to the society.

The concept of Buy-One Give-One (BOGO) is well-known since TOMS Shoes introducing the buy-one give-one concept in 2006. Initially the founder, Blake Mycoskie, went to Afghanistan and found out there are poor children who live at under-privilege economy and live without wearing any proper shoes. Therefore, he initiatively adapts this BOGO concept and channeled throughout the developing countries. This concept became a powerful marketing communication strategy as global firms nowadays understand the importance to combine it with the values in its corporate social responsibility program (Sekarwangi, 2018).

The business idea is widely embraced and successfully inspired other entrepreneurs to implement this concept (Marquis \& Park, 2014). For example, Warby Parker was successfully donating their 100,000 glasses to the poor people. This concept of social entrepreneurship also aligns with the idea of social marketing strategy. Social marketing involves the activity or effort and offering the benefits in the society (Basil et al., 2019). Social marketing aims to enhance and integrate marketing concepts along with other approaches to encourage positive attitude among individuals and group for the greater social impact. The implementation of social marketing practice is based on ethical principles. It requires research integration, best practice, and partnership to deliver respective social programs that sustainable and effective. Therefore, the existence of social entrepreneurship will ease and enrich social wellbeing and achieve the organization's economic agenda.

The millennial generational group are people who were born between 1980 and 2000 (DeVaney, 2015). They are categorized as the millennial generation because they were born in the millennium age and raised in the more digital era than the earlier generation. This generation was influenced by massive development of technology and modern values. Previous study addresses that millennial as a young generation is having a massive impact on the social environment and the workplace (Burke et al., 2015). The characteristic of the millennial generation is having better expertise in the technology, and they tend to set the values of self-expression, a balanced lifestyle, and a flexible working environment, combined with resilient and social responsibility. Another study by 
Nurficahyanti (2015) mention the importance of young people in promoting traditional products such as traditional batik cloths produced by local batik crafter communities, because they are more adoptive to the use of new marketing communication technology.

Brand awareness is one of the fundamental things in brand equity. Brand awareness associates with the consciousness of the customer to purchase the product of society (Aaker, 1991). Brand awareness has a strong association with an individual's memory to identify the brand in various moments and condition (Keller, 1993). The ways consumer will remember the brand is strongly affected by the perception that a specific product will stays on the individual's memory. According to this theory, the unaware of brand is considered as the lowest level of the brand awareness pyramid; essentially, the customer does not have the awareness or consciousness of the brand (Aaker, Managing Brand Equity, 1991). In the stage of the unaware, people never heard about the respective brand. For instance, they have no clue about the characteristic of the brand, the logo, the place selling this brand and everything that related with the brand. There are several ways to build up brand awareness towards the customer that can be categorized into four categories; they are: the anchor to which other associations can be attached, familiarity, substance/commitment, and brand to consider.

Perceived quality can be described as the condition that being perceived by the customer towards the whole quality of the brand (Aaker, 1996). The perceived quality from the consumer has a function to differentiate each brand with another brand in the same industry. The good perceived quality is the ability of the brand to produce a reasonable price with good quality. Meanwhile, another author mentions the perceived quality as the dimension of a whole part of the brand equity, instead of the brand association only (Gordon, 1994).

The perceived quality can be described as the customer perception about the overall product superiority, instead of focusing on the objective condition (Zeithaml, 1988). In this case, a certain quality can be described as the measurable, verifiable nature of the product or service, and it includes quality and control. Another author also mentions the objective condition is not affecting the actual quality of the brand (Anselmsson et al., 2007). It means the objective condition is not changing the brand equity, since it is difficult to make a precise analysis of the objective quality of the brand. Therefore, most of the people are using the quality attributes to assess the brand, instead of the objective attitudes (Boulding et al., 1993).

In general, the concept of perceived quality is classified into two categories, which are intrinsic attributes and extrinsic attributes, as proposed by Zeithaml (1988). The intrinsic qualities can be correlated as the physical aspect of the product, such as: color, appearance, and physical form, as a characteristic of the physical essence of the brand. On the other hand, the extrinsic aspect of the brand is not included in the physical nature of the brand. The external component can be seen from the extraneous attribute of the product or service, such as the name of the brand, the logos, the price, the packaging, the function, and the value of the brand. Conclusively, the perceived quality is the indicators 
that value the brand from its intrinsic and the extrinsic values, instead of looking on the physical condition of the brand.

The brand association is often related to the term of "image". The term was popular around 1950s; this "image" or "association" words often used to create a meaningful value on a country image, brand image, company image, and many more. It can be said that an image can be classified as a reputable and impression of the individual toward something (Armstrong \& Kotler, 2015). According to Aaker (1991), anything linked in memory to a brand is categorized as a brand association. It indicates that the brand association is relatable with the brand that more reliable when it is based-on exposures that have experienced by the customer. Further, in the same light, he also mentions that the brand association provides a fundamental reason from the consumer and attract them to buy the specific brand by giving a positive feeling among the consumers.

Brand loyalty is a necessary and fundamental aspect of brand equity (Aaker, Managing Brand Equity, 1991). Another author describes brand loyalty as another description that can be associated with the consumer behavior of the re-purchase of stuff in several marketplaces or physical stores (Keller, 1993) or the dedication to re-purchase the same brand in a certain period. The brand loyalty that up in the first mind of the customer is often associated with the "top of mind". This kind of loyalty can be called as cognitive loyalty. In other words, brand loyalty can be categorized as the ability of the people to cope with the first choice (Keller, 1993). Brand loyalty also associates with the brand price (Chaudhuri, 1995). As the brand offers affordable price with a better quality, it will affect to the higher loyalty.

According to Keller (2003) the brand loyalty plays prominent role in the customer's decision making by conveying three rewards, such as: learning advantage, consideration advantage, and choice advantage. In addition, the brand loyalty consists of several important factors that will influence the purchase intention, such as: brand name, design of the product, price, the store environment in which those factors will influence the purchase intention of the customer to purchase respective brand or product (Hameed \& Kanwal, 2018).

The brand credibility is the customer decision to perceive trustworthiness of the brand (Jeng, 2016). In this case the trustworthiness is the eagerness of the company to deliver the brand with the value that the company promised. The brand credibility depends on how the customer trusts the brand as a reputable brand and would influence the customer to buy the brand. Furthermore, the brand credibility has a function to communicate the brand to the consumer (Sweeney \& Swait, 2008). Hence, it would create an effective communication in delivering the brand value to the customer. Brand credibility has a positive impact towards purchase intention (Jeng, 2016) and refers to the believes of the consumers toward the respective product or brand. There are several brand credibility elements, which consist of trustworthiness, expertise, and attractiveness (Wang \& Yang, 2010). The trustworthiness refers to the consumer's trust toward the brand. Meanwhile, the expertise refers to the 
believes of the consumer toward the brand in their capability to deliver the value. In addition, the attractiveness can be described as likeableness.

Some empirical evidence mention that the brand equity can affect the purchase intention in respective context (Chang \& Liu, 2009). The brand awareness brings three advantages in determining the customer to intervene their purchasing decision (Keller, 1993). Those three advantages can be classified into: the learning advantages, choice advantages, and consideration advantages. Further, the brand associations are corresponding to a fundamental for purchase decision and it creates value for both organization and the customer. The benefit of brand associations can be considered as to acquire or process the information, differentiate the brand, leveraging reasons to buy, create positive feelings and attitude (Aaker, 1991). The relationship between purchase intention and the perceived quality is quite the same as brand association. The perceived quality also provides value to the consumers by accommodating the customer with reason to buy and by differentiate the brand from another competitor's brands.

As discussed earlier, the brand loyalty strongly influences the purchase intention of the customer and encouraged the customer to be loyal of the brand. Therefore, this study investigates how the purchase intention has a strong correlation with each brand equity element that consists of brand awareness, perceived quality, brand association, brand loyalty, and brand credibility.

There were few past studies conducted to measure the branding aspects toward the purchase intention. The research conducted by Jalilvand et al. (2011) applied four branding aspects of brand awareness, perceived quality, brand association, brand loyalty variables to measure its effect to the purchase intention. However, this study did not include the effect of brand credibility. Another study from Jeng (2016) tested the effects of brand credibility, decision convenience, and affective commitment toward the purchase intention. However, it did not consider the branding aspects as discussed by Jalilvand (2011). Those two studies were conducted in transportation industry settings (automobile and airline). Therefore, this study is trying to fill the theoretical gap of the preliminary branding studies by integrating the five branding aspects to measure the branding elements effects toward purchase intention of charity product.

\section{RESEARCH METHODS}

The approach used in this research is quantitative method that involves the calculation of numerical data. This quantitative method uses linear regression model to analyze the data from the developed construct of variables. This study is done by using online survey method through distributed questionnaires. The mechanism of the distribution of the online questionnaire is by using Google Form as a popular and practical online platform for the millennial respondents. It is also aimed to anticipate the social distancing practices during the Covid-19 global pandemic. The questionnaires were developed so as each independent variable has three items of valid and reliable questions, after tested by using KMO and Cronbach Alpha statistical tests taken from 30 valid respondents. 
The model has several variables that consist of five independent variables; they are: Brand Awareness $\left(\mathrm{X}_{1}\right)$, Perceived Quality $\left(\mathrm{X}_{2}\right)$, Brand Association $\left(\mathrm{X}_{3}\right)$, Brand Loyalty $\left(\mathrm{X}_{4}\right)$, and Brand Credibility $\left(\mathrm{X}_{5}\right)$. The dependent variable is Purchasing Intention $(\mathrm{Y})$. The survey was conducted around four months, starting from March 2020. This research involves the participation of the millennial' respondents who are living and commuting within Jakarta and its greater area or we called it as Jakarta metropolitan area (Jakarta, Bogor, Depok, Tangerang, Bekasi) area. The valid and reliable questionnaires were directly distributed online to the potential respondents that are qualified to participate for this study, those who already recognized the YoI brand shoes.

The population of people who live in Jakarta and its surrounding based-on the Indonesian Center Bureau of Statistics is around 10.5 million people (Jayani, 2019). Therefore considering 1\% error of non-probability sampling based-on Slovin's formula, the minimum number of samples required is 100 respondents. However, this study successfully collected 222 valid respondents, which indicates that the study is exceeding the minimum criteria.

There are 5 hypotheses developed in this study, whether the Brand Awareness $\left(\mathrm{H}_{1}\right)$, Perceived Quality $\left(\mathrm{H}_{2}\right)$, Brand Association $\left(\mathrm{H}_{3}\right)$, Brand Loyalty $\left(\mathrm{H}_{4}\right)$, and Brand Credibility $\left(\mathrm{H}_{5}\right)$ significantly affect the Purchase Intention of BOGO charity product. Further, this study uses multiple regression model to examine and analyze the data by using reputable statistical software. The linear regression model in this study is reflected in the following equation:

$$
Y=\beta_{0}+\beta_{1} X_{1}+\beta_{2} X_{2}+\beta_{3} X_{3}+\beta_{4} X_{4}+\beta_{4} X_{5}+e
$$

Notes:

$\mathrm{Y}=$ Intention to Purchase;

$\mathrm{X}_{1}=$ Brand Awareness (BAW);

$\mathrm{X}_{2}=$ Perceived Quality (PQ);

$\mathrm{X}_{3}=$ Brand Association (BAS);

$\mathrm{X}_{4}=$ Brand Loyalty $(\mathrm{BL})$;

$\mathrm{X}_{5}=$ Brand Credibility $(\mathrm{BC})$;

$\beta_{1}, \beta_{2}, \beta_{3}, \beta_{4}=$ Coefficients;

$\mathrm{e}=$ Error. 


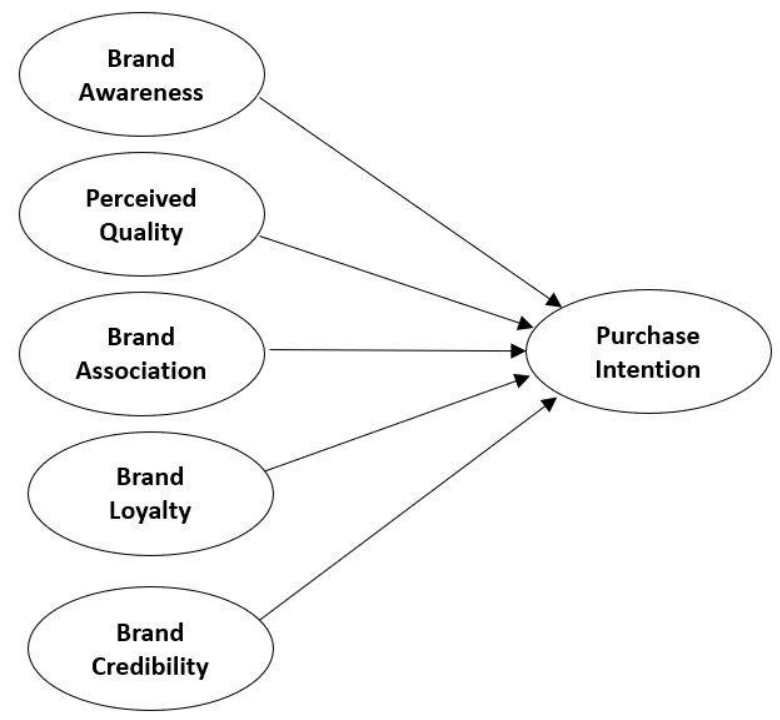

Figure 1. Research Framework Source: Author

\section{RESULTS AND DISCUSSION}

There are two measurements that need to consider: the tolerance value and the Variance Inflation Factor (VIF). The rules of thumb of the multicollinearity test are that the tolerance value shall be above 0.1 and the VIF value shall be below 10 , so it is suitable with the criteria that the regression model is free from multicollinearity. Based-on the test output it concludes that all independent variables are free from multicollinearity.

The output of multiple linear regression it shows that the $\mathrm{R}$ value of this model is 0.783 . This result indicates that there is a moderately strong correlation of its linear relationships. The purpose of analyzing the $\mathrm{R}$ square $\left(\mathrm{R}^{2}\right)$ is to determine the relationships between the independent variables and the dependent variable in the respective model. Hence, the result of the R square model is 0.613 , or it indicates that $61.3 \%$ of the intention to purchase YoI shoes can be explained or related to the brand awareness, perceived quality, brand association, brand loyalty, and brand credibility factors. Meanwhile the rest of $38.7 \%$ is affected by other variables that do not include in the model. In addition, the adjusted $\mathrm{R}$ square $\left(\mathrm{R}^{2}\right)$ indicates the percentage of the data toward the regression model according to the dependent variable in the respective model. The result shows that 0.604 or $60.4 \%$ of this model can be elaborated and explained by those five-independent variables.

In this section, the normality test is conducted by computing its Kolmogorov Smirnov test. The purpose of examining the normality test is to determine whether the residual data is normally distributed or not. The regression model can be categorized as a good model when it is normally distributed. The rule of thumb of this model is if the significant value is $>0.005$, hence the residual value is normally distributed. Meanwhile, if the significant value is $<0.05$, therefore the residual value is not normally distributed. According to output, the result of normality test is 0.200 , which is indicating that its p-value is $>0.005$. Therefore, it can be concluded that the residual value is normally distributed. 
The F-test is used to determine the effect of the independent variables toward the dependent variable. This study uses 5\% significance level. The F-test can be conducted with two methods. The first method is by comparing F-statistic value and its F-table values. If the F-statistic value is higher than the F-table value, then the null hypothesis $\left(\mathrm{H}_{0}\right)$ is rejected. On the other hand, if the F-statistic value is lower than the F-table value, $\mathrm{H}_{0}$ is not rejected.

The result of F-test was 68.446 . Then the $\mathrm{df}_{1}$ is 5 , and the $\mathrm{df}_{2}$ is 216 . Therefore, the F-table value based-on this model is 2.26 . The F-statistic value of the model is higher than the F-table value (68.446 > 2.26), so it indicates that the $\mathrm{H}_{0}$ is rejected and $\mathrm{H}_{1}$ is accepted. The second method to determine the F-test result is through comparing its significance indicator to the $\alpha(=0.05)$. If the value of the sig. $<\alpha$ (for example $0.000<0.005$ ), it means that the model is significant. According to its output of 0.000 , therefore the model can be concluded as significant.

Based-on the t-test model on each independent variable, the study found that the $\mathrm{X}_{1}$ variable (Brand Awareness) is 0.190 or greater than 0.05. Meanwhile, the computation output of the t-test value is 1.314 which was smaller than the t-table value of 1.972. Therefore, it indicates that the BAW variable is not significant, or the null hypothesis $\left(\mathrm{H}_{0}\right)$ is accepted and the $\mathrm{H}_{1}$ is rejected. Further t-test on $\mathrm{X}_{2}$ variable (Perceived Quality) resulted its p-value of 0.470 or greater than 0.05 . And the t-test value was -0.724 which is smaller than the $t$-table values of 1.972 . It confirmed that the PQ variable was also not significantly affected the purchase intention. The p-value of $\mathrm{X}_{3}$ variable (Brand Association) is 0.924 and the t-test value is -0.960 or less than the t-table value of 1.972 . Like the previous independent variables, it shows that this variable is not significantly influence purchase intention.

However, the t-tests for the remaining two independent variables shows different results. The $\mathrm{p}$-value for $\mathrm{X}_{4}$ variable (Brand Loyalty) is 0.000 ; it indicates that the $\mathrm{p}$-value < alpha-value, which is $0.000<0.005$. Meanwhile, the t-test value is 7.112 , which is greater than the t-table value of 1.972 . Therefore, it can be concluded that the BL variable significantly influence the purchase intention. Finally, the t-test resulted on $\mathrm{BC}$ variable shows that its p-value is 0.000 and the t-test value is 7.730 , which is greater than the t-table value of 1.97 . It also can be concluded that this $\mathrm{X}_{5}$ variable significantly influence the purchase intention.

According to regression model output, the final equation of the purchase intention model of the Youth of Indonesia shoes can be summarized as follows:

$$
\mathrm{Y}=1.400+0.064 \mathrm{BAW}-0.052 \mathrm{PQ}-0.005 \mathrm{BA}+0.388 \mathrm{BL} *+0.529 \mathrm{BC} *
$$

Out of the five independent variables, there are two variables that have negative values toward the dependent variable (purchase intention). Those variables are the $X_{2}$ (Perceived Quality) and $X_{3}$ (Brand Association) while the other three independent variables show positive relationships toward the dependent variable; they are $\mathrm{X}_{1}$ (Brand Awareness), $\mathrm{X}_{4}$ (Brand Loyalty), and $\mathrm{X}_{5}$ (Brand Credibility). The brand awareness has a positive value, but after conducting the t-test, it shows that its value is not significantly influence purchase intention. However, as for the brand loyalty and the brand credibility, 
it shows that the result of the t-test is positive and significantly influence the purchase intention. According to the model above, it can be concluded that the brand credibility is the most significant variable that influence the purchase intention of YoI shoes, which is 0.529. On the other hand, the perceived quality is the variable that has the lowest influence toward the dependent variable of YoI purchase intention.

Based on the t-test result, it reveals that the brand awareness is one of the variables that has no significant effect toward the purchase intention on YoI shoes. This finding is consistent with another research finding addressed that the brand awareness is not directly influenced the purchase intention of ACE Hardware products (Widjaja, 2019). Another study also mentions that awareness has no significant effect towards the purchase intention for a candy product (Suryadi, 2015). According to Aaker and Keller (1990), when a business tried to develop a new product, it is necessary for business to actively promote their new product. Therefore, it will lead to stronger brand awareness. In other words, the insignificant value of the brand awareness toward purchase intention may due-to the new brand of YoI is considered as not been actively promoted yet. This is supported with the evidence that this brand has not been included in the top of mind of the shoe's consumer in Indonesia. It can be seen from the respondents who fill the questionnaire, which is many of them do not know about YoI product or brand before.

The second dependent variable of perceived quality apparently has no significant influence toward the purchase intention of YoI.

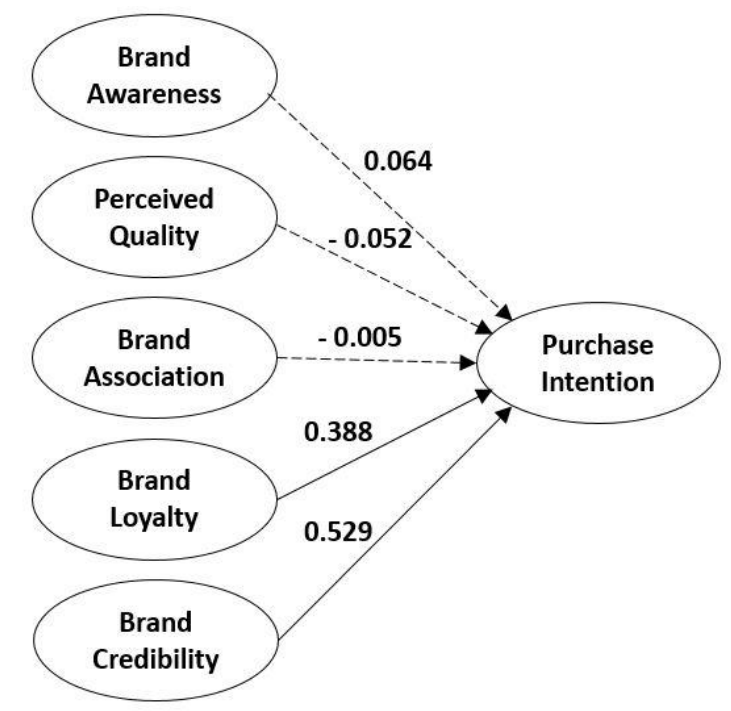

Figure 2. Research Framework Output

Source: Author

This finding is consistent with previous study by Alinegoro (2014) that addresses the perceived quality has no significant toward the purchase intention of clothing product, due-to the trust factor from the customer toward the brand might stronger than the perceived quality of the product. In this case, the brand credibility affects more significantly toward the purchase intention of YoI. In addition, YoI shoes is considered as charity product that includes in its BOGO program. The customer might ignore the 
Winarko, H.B., Benning, L.S., \& Pannindriya, S.T. (2021). The Branding Impact on Charity ....

quality aspect because the social motive of buying. This means that the customers will buy the product anyway, no matter how good the quality of the product is. Another study mentions that the perceived quality also does not significantly affect the purchase intention, because of it is applied in different industry and country which may lead to different contexts (Santoso \& Cahyadi, 2014).

The finding of this study shows that the brand association has no significant effect on the purchase intention of YoI shoes. This result is consistent with the finding of previous study in the laptop product (Fitri et al., 2018). This result can be justified in the case of YoI shoes, due-to the fact that this brand has not been strongly positioned yet, targeted to a niche youth community.

The fourth factor of brand loyalty shows a positive impact toward the purchase intention. It indicates that the respondents believe that YoI brand able to deliver a valuable meaning that may enhance its customer trust toward YoI shoes in the long run. Similarly, the fifth factor of brand credibility also plays as important role in the purchasing of YoI shoes. According to the output, the brand credibility is apparently considered as the most dominant variable that affecting the purchase intention toward the purchase intention of YoI brand shoes.

\section{CONCLUSION AND RECOMMENDATION}

There is no significant relationship between brand awareness and purchase intention of YoI brand shoes as the brand wants to position itself as a Buy-One Give-One (BOGO) charity product. The consumer's motivation to purchase this product may dominantly influenced by its social mission, rather than the brand's perceived quality value. The study found that the relationship between brand loyalty and purchase intention of YoI shoes is positive and significant. It means that existing YoI brand loyal customers are likely willing to re-purchase YoI brand shoes in the future.

The study also found that the brand credibility is the most significant factor for millennial to purchase YoI brand shoes. It means that the brand of YoI as a charity brand shoes has strong capability to deliver its social value, in-order to attract or influence potential customers to purchase their products. It is recommended to Youth of Indonesia to improve its digital marketing strategy so as it can expand more customers to purchase and re-purchase the products. Creative loyalty program can be implemented further. There is limitation of this study as the survey was conducted in Jakarta and its greater area dueto current Covid-19 pandemic condition. However, the novelty of this study can be used as the basis for further study in another BOGO products. 


\section{REFERENCES}

Aaker, D. A. (1991). Managing Brand Equity. New York: Free Press.

Aaker, D. A. (1996). Measuring Brand Equity Accross Products and Markets. California Management Review, 38(3), 102-120. doi:10.2307/41165845

Alinegoro, I. H. (2014). Pengaruh Elemen Ekuitas Merek (Brand Equity) terhadap Keputusan Pembelian Produk Pakaian (X) S.M.L. di Surabaya. Jurnal Gema Aktualita, 3(1), 32-43.

Armstrong, G., and Kotler, P. (2015). Marketing: An Introduction (12th ed.). Pearson.

Basil, D. Z., Diaz-Meneses, G., and Basil, M. D. (2019). Social Marketing in Action: Cases from Around the World. Springer. doi:10.1007/978-3-030-13020-6

Boulding, W., Kalra, A., Staelin, R., and Zeithaml, V. A. (1993). A Dynamic Process Model of Service Quality: From Expectations to Behavioral Intentions. Journal of Marketing Research, 30(1), 7-27. doi: $10.2307 / 3172510$

Burke, R. J., Cooper, C. L., and Antinou, A.-S. (2015). The Multi-generational and Aging Workforce: Challenges and Opportunities. ElgarOnline. doi:10.4337/9781783476589

Cathcart, R. J., and Killen, E. J. (1940). Scoring of Toast and Factors Which Affect Quality. Journal of Food Science, 5(3), 307-321.

Chaudhuri, A. (1995). Brand equity or double jeopardy? Journal of Product \& Brand Management, 4(1), 26-32. doi:10.1108/10610429510083730

DeVaney, S. A. (2015). Understanding the Millennial Generation. Journal of Financial Service Professionals, 69(6), 11-14.

Fitri, N. R., Rini, E. S., and Sembiring, B. F. (2018). The Effect of Brand Equity on Purchase Decisions Laptop Toshiba in Magister Students Faculty Economic and Business USU. International Journal of Scientific and Technology Research, 7(4), 64-71.

Gillespie, N. (2014, August 21th). Millennials Are Selfish and Entitled, and Helicopter Parents Are to Blame. Retrieved from TIME: https://time.com/3154186/millennials-selfish-entitled-helicopterparenting/ 
Winarko, H.B., Benning, L.S., \& Pannindriya, S.T. (2021). The Branding Impact on Charity ....

Gordon, G. L., di Benedetto, C. A., and Calantone, R. J. (1994). Brand equity as an evolutionary process. Journal of Brand management, 2(1), 47-56. doi:10.1057/bm.1994.31

Hameed, S. and Kanwal, M. (2018). Effect of Brand Loyalty on Purchase Intention in Cosmetics Industry. Research in Business and Management, 5(1), 25-35. doi:10.5296/rbm.v5i1.12704

IDN Research Institute. (2019). Indonesia Millenial Report 2019: Understanding Millennial's Behaviours and Demystifiying Their Stereotypes. IDN Media. Retrieved from https://www.idntimes.com/indonesiamillennialreport2019

Jayani, D. H. (2019, September 10th). umlah Penduduk DKI Jakarta 2019 Mencapai 10,5 Juta Jiwa. (H. Widowati, Editor) Retrieved from Databoks: https://databoks.katadata.co.id/datapublish/2019/09/10/jumlah-penduduk-dki-jakarta-2019mencapai-105-juta-jiwa

Jeng, S. P. (2016). The influences of airline brand credibility on consumer purchase intentions. Journal of Air Transport Management, 55, 1-8. doi:10.1016/j.jairtraman.2016.04.005

Keller, K. L. (1993). Memory Retrieval Factors and Advertising Effectiveness. In A. A. Mitchell (Ed.), Advertising Exposure, Memory and Choice (pp. 11-48). Hillsdale, NJ: Lawrence Erlbaum Associates.

Koczanski, P. and Rosen, H. S. (2019). Are Millennials Really Particularly Selfish? Preliminary Evidence from a Cross-Sectional Sample in the Philanthropy Panel Study. American Behavioral Scientist, 63(14), 1965-1982. doi:10.1177/0002764219850871

Marquis, C. and Park, A. (2014). Inside the Buy-One Give-One Model. Retrieved December 12th, 2020, from Standford Social Innovation Review: https://ssir.org/articles/entry/inside the buy one give one model\#

Purnamasari, D. (2018, June 5th). Generasi Milenial Suka Memberi Sumbangan. (N. Q. Pramisti, Editor) Retrieved December 20th, 2020, from Tirto.id - Gaya Hidup: https://tirto.id/generasimilenial-suka-memberi-sumbangan-cLHu

Santoso, C. R. and Cahyadi, T. E. (2014). Analyzing the Impact of Brand Equity towards Purchase Intention in Automotive Industry: A Case Study of ABC in Surabaya. iBuss Management, 2(2), 29-39. 
Schulte, B. (2015, June 24th). Millennials are actually more generous than anybody realizes. Retrieved December 20th, 2020, from The Washington Post - Economic Policy: https://www.washingtonpost.com/news/wonk/wp/2015/06/24/millennials-are-actually-moregenerous-than-anybody-realizes/?noredirect=on

Suryadi, D. (2015). The Impact of Brand Equity towards Purchase Intention on PT. X's Candy. iBuss Management, 3(2), 1-8.

Sweeney, J. and Swait, J. (2008). The effects of brand credibility on customer loyalty. Journal of Retailing and Consumer Services, 15(3), 179-193. doi:10.1016/j.jretconser.2007.04.001

Wang, X. and Yang, Z. (2010). The Effect of Brand Credibility on Consumers' Brand Purchase Intention in Emerging Economies: The Moderating Role of Brand Awareness and Brand Image. Journal of Global Marketing, 23(3), 177-188. doi:10.1080/08911762.2010.487419

Widjaja, Y. G. (2019). Effect of Brand Awareness, Brand Association, Perceived Quality and Brand Loyalty on Purchasing Decision: Case Study on ACE Hardware Indonesia Consumers. International Journal of Advanced Engineering, Management and Science, 5(9), 542-548. doi:10.22161/ijaems.59.1

Zeithaml, V. A. (1988). Consumer Perceptions of Price, Quality, and Value: A Means-End Model and Synthesis of Evidence. Journal of Marketing, 52(3), 2-22. doi:10.1177/002224298805200302 